\title{
Research on the Practice of Pension Finance under the Background of Digital Economy
}

\author{
Da Deng, Huafeng Li* \\ China University of Political science and Law
}

\begin{abstract}
The rapid growth of the aging population makes China's aging problem more serious. Due to the lack of material basis and the low degree of socialization of the existing pension security mechanism, it is difficult to meet the needs of the residents, so we can only rely on the policies issued by the government and relevant departments. Under the new situation, the solution of pension problem depends on the development of finance to a great extent, and the pension problem has been put on the agenda. With the outbreak of the world financial crisis in 2008, digital economy came into being and developed rapidly. As a new economic form, digital economy is becoming the main driving force of economic development efficiency change, quality change and dynamic change. In order to solve the practical development problems of pension finance in China, this research is carried out. Based on the above background, this study combines the actual situation of China's pension finance, introduces digital economy into China's pension finance, and further develops the practical problems of China's pension finance with the help of digital economy. This study investigates the current situation of China's pension finance, and through the analysis of the survey results, puts forward suggestions for the development of pension finance in China, so as to provide certain reference for the design and formulation of policies.
\end{abstract}

\section{INTRODUCTION}

Under the background of aging population [1], the problem of providing for the aged [2] has become one of the most prominent and serious contradictions in the process of social and economic development in China. According to statistics, by the end of 2018, there will be about 250 million elderly people over the age of 60 , accounting for nearly $18 \%$ of the total population; in the past 20 years, China's elderly population has increased by 119 million; it is estimated that by 2050 , China's elderly population will reach 487 million [3]. When China's elderly population arrives in China, China will become one of the most aging countries in the world [4]. The aging of the population will not only lead to structural problems of the population, but also lead to a sharp decline in the proportion of China's labor force, which makes the supply of various social welfare more difficult, and will gradually become a social problem, hindering the rapid development of social economy [5].

From the theoretical level, we should face the current situation, re-examine and position the pension problem, and actively explore and improve the pension security [6] and service system [7]. On this basis, to ensure that it can effectively cover the needs of China's elderly population, and truly realize the purpose of pension. It should be emphasized that the construction and development of the endowment insurance system [8] cannot be separated from the support of the market and various social funds. In a sense, finance makes the domestic market economy get better development, and also plays a very important role in the optimal allocation of resources [9]. According to the research theory, it is imperative to guide the development of domestic financial industry and increase the investment in pension service industry. The development of pension financial industry should actively meet the needs of service system construction and development, innovate and improve the level of financial services, comprehensively promote the development of pension finance in China, and promote the development of pension industry [10].

This paper investigates the current situation of pension finance in China, and finds out the problems and deficiencies in the development of pension finance industry. At the same time, this paper introduces the concept of digital economy and combines the development of pension finance with digital economy. Based on the background of digital economy, this paper puts forward suggestions on the development of pension finance in China, and provides some reference for the design and formulation of policies.

\section{Pension Finance And Digital Economy}

\subsection{Pension Finance}

As for the theoretical connotation of pension finance, there are still disputes in academic circles, and there is no 
unified standard. Blake is a British researcher who uses the concept of "pension finance" in his monograph "pension finance". He believes that pension finance mainly refers to the financial market, real estate market, financial products market and other investment markets of pension funds. In China, there are two concepts of pension finance and pension service finance. But they are often used together, and there is no strict difference in connotation. He Qiang believes that China should establish a more comprehensive pension financial system, which should include basic pension insurance, enterprise annuity, commercial endowment insurance, pension savings, housing reverse mortgage loan, endowment insurance, pension trust and other pension financial services. Therefore, the pension finance here is actually the connotation of pension service finance. Hu Jiye also equated pension finance with pension service finance. He believes that pension finance or pension service finance mainly invests in the market directly and indirectly in the market. By studying the investment of pension assets, the value of assets can be maintained and increased, and then the development of pension financial market is promoted.

\subsection{Digital Economy}

In the world, digital economy is generally an exponential application, which is similar to information economy (information refers to things related to information technology). Its scope is larger than Internet economy or network economy. The connotation of digital economy has three important characteristics: digitalization, networking and intellectualization. The G20 initiative on digital economy development and Cooperation issued at the G20 Hangzhou summit in 2016 pointed out that the digital economy is in fact similar to this kind of economic activities. Digital knowledge and information are the key factors of production in digital economy. Modern information network is an important carrier of digital economy. At the same time, digital economy can make full use of information and communication technology, which is an important power to improve efficiency and optimize economic structure. This means that the concept of digital economy has been widely recognized by the international community. There are three main modes of Digital

Economy: the first is the basic digital economy, such as electronic equipment manufacturing and information manufacturing; the second is the integration of digital economy, such as the combination of traditional industries such as e-commerce and digital technology; the third is the emerging digital economy, such as mobile payment, live broadcast platform, network crowd funding business, etc.

\section{ReseARCH IDEAS AND MethodS}

After the 1990s, China began to realize the importance of the reform of the old-age security system and focused on the social security. However, in recent years, the problem of pension finance has only begun to receive attention, and the research related to pension finance has just begun and is in the initial stage of development. The research on Pension Finance in China started late, mainly concentrated in the recent 20 years of the new century. Compared with the mature theoretical system of foreign countries, domestic theoretical research is more specific, in line with the market trend of the development of pension finance. The research mainly focuses on the reform and development of pension security system, operation and supervision of pension assets, and lacks of in-depth analysis on the direction of pension finance of commercial banks. Few of these researches mostly stay in the development of pension finance of commercial banks there are few qualitative studies on the driving force of business and the path of commercial banks to develop pension financial business, which leaves a huge research space for this paper. First of all, based on the existing pension theory and financial theory, combined with domestic and foreign research results and theoretical views, this paper analyzes and summarizes the current situation of pension finance in China. In this paper, a large number of statistical data and statistical charts are used to analyze the relevant data of pension asset scale, pension asset scale and market trend in China, so as to provide reference for the future development of pension finance.

\section{Discussion}

\subsection{Analysis of Survey Results}

Table1. Enterprise Annuity Pension Products in 2019

\begin{tabular}{|c|c|c|c|c|c|c|}
\hline \multirow{2}{*}{\multicolumn{2}{|c|}{ Product Type }} & \multicolumn{2}{|c|}{ Number of Products } & \multirow{3}{*}{$\begin{array}{l}\text { Net Assets at the } \\
\text { End of the Period } \\
\text { (10000 yuan) } \\
4687057.55\end{array}$} & \multirow{3}{*}{$\begin{array}{c}\text { Return on } \\
\text { Investment } \\
\text { since This } \\
\text { Year } \\
3.60\end{array}$} & \multirow{3}{*}{$\begin{array}{c}\text { Cumulative } \\
\text { Rate of Return } \\
\text { since Its } \\
\text { Establishment } \\
15.19\end{array}$} \\
\hline & & Filed & Actual & & & \\
\hline \multirow{7}{*}{$\begin{array}{l}\text { Fixed } \\
\text { Income }\end{array}$} & Ordinary & 57 & 29 & & & \\
\hline & Deposit & 7 & 4 & 253789.50 & 5.41 & 9.74 \\
\hline & Bond & 17 & 6 & 1382422.83 & 4.51 & 6 \\
\hline & Bond Fund & 5 & 2 & - & - & - \\
\hline & $\begin{array}{c}\text { Financial } \\
\text { Products of } \\
\text { Commercial } \\
\text { Banks }\end{array}$ & 2 & 0 & 423842.27 & - & 0.19 \\
\hline & Trust Products & 34 & 15 & 3165825.99 & 6.20 & 12.9 \\
\hline & Debt Plan & 17 & 10 & 1200078.70 & 6.14 & 15.7 \\
\hline
\end{tabular}




\begin{tabular}{|c|c|c|c|c|c|c|}
\hline & $\begin{array}{c}\text { Specific Asset } \\
\text { Management } \\
\text { Plan }\end{array}$ & 13 & 0 & 10841.20 & 7.14 & 11.62 \\
\cline { 2 - 7 } & $\begin{array}{c}\text { Insurance } \\
\text { Products }\end{array}$ & 0 & 1 & 248778.88 & - & 1.67 \\
\cline { 2 - 7 } & Other & - & - & - & - & - \\
\cline { 2 - 7 } & Total & 152 & 67 & 11378462.60 & 4.79 & 12.20 \\
\hline
\end{tabular}

Shown as Table 1, the table summarizes the pension products of enterprise annuity in 2019. At present, insurance companies have special endowment insurance products. Fund companies issue pension funds, trust companies issue pension trust plans, and some banks also issue pension financial products. However, some banks, especially large commercial banks, have not yet launched personalized financial products for elderly customers, nor have they launched credit services and service strategies for the pension industry chain.

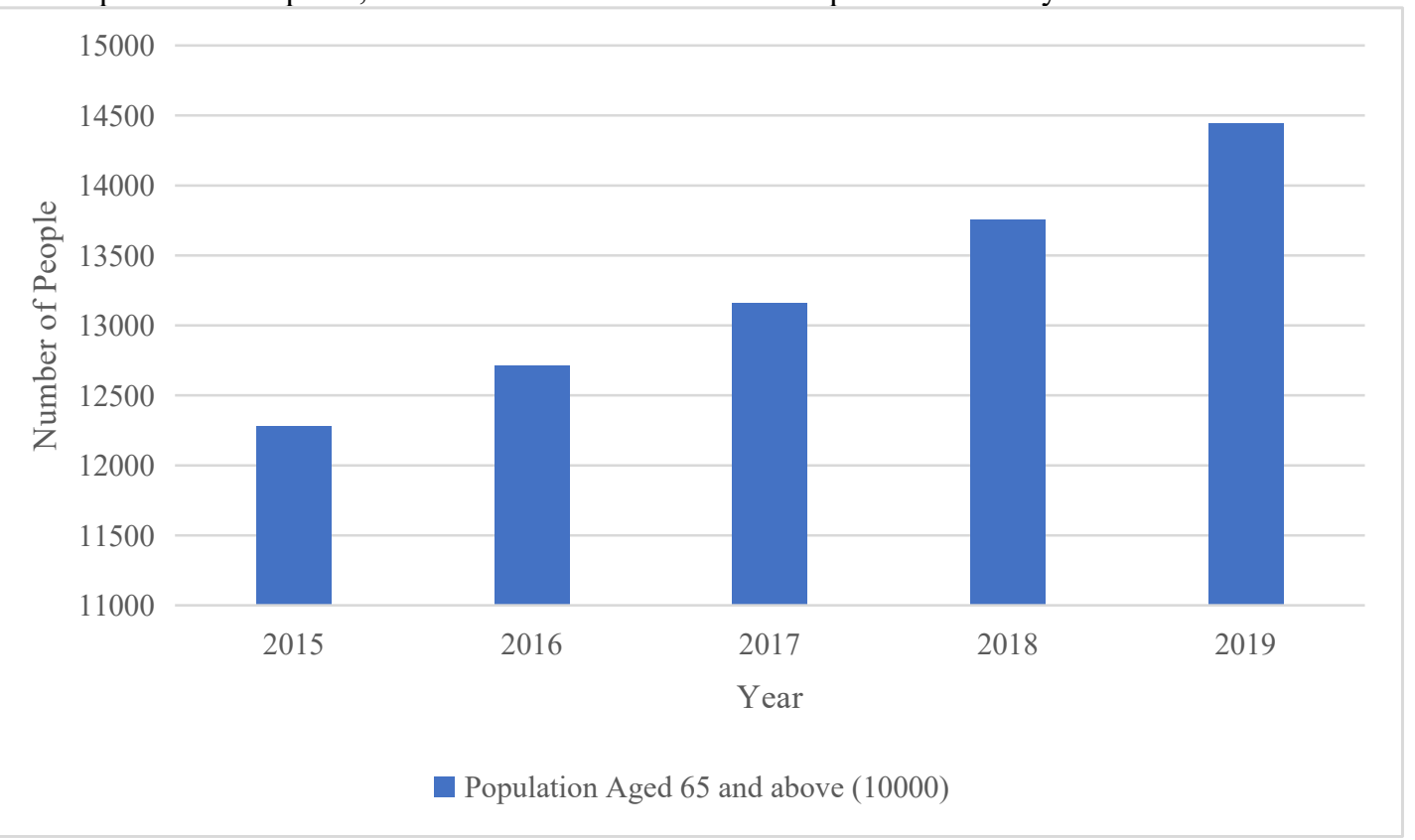

Figure 1. Trends of Population Aged 65 and above in China from 2015 to 2019

Shown as Figure 1, in 2015, China's population aged 65 and above was about 120 million. In the past decade, China's population over 65 has been growing rapidly every year. According to the national statistics, in 2016, China's population over 65 years old will reach about 230 million, accounting for about $16 \%$ of the total population; some experts predict that by 2020, China's elderly population will exceed 250 million; by 2025, China's elderly population over 60 will reach 300 million, and the aging level will be close to $20 \%$. This means that in another 10 years, China will enter an aging society as a whole, and some regions will enter an over age society. If this situation continues to develop, the dividend brought by the population will gradually disappear, and then the labor force that can create value will gradually decrease, and the pension problem will become more and more serious. 


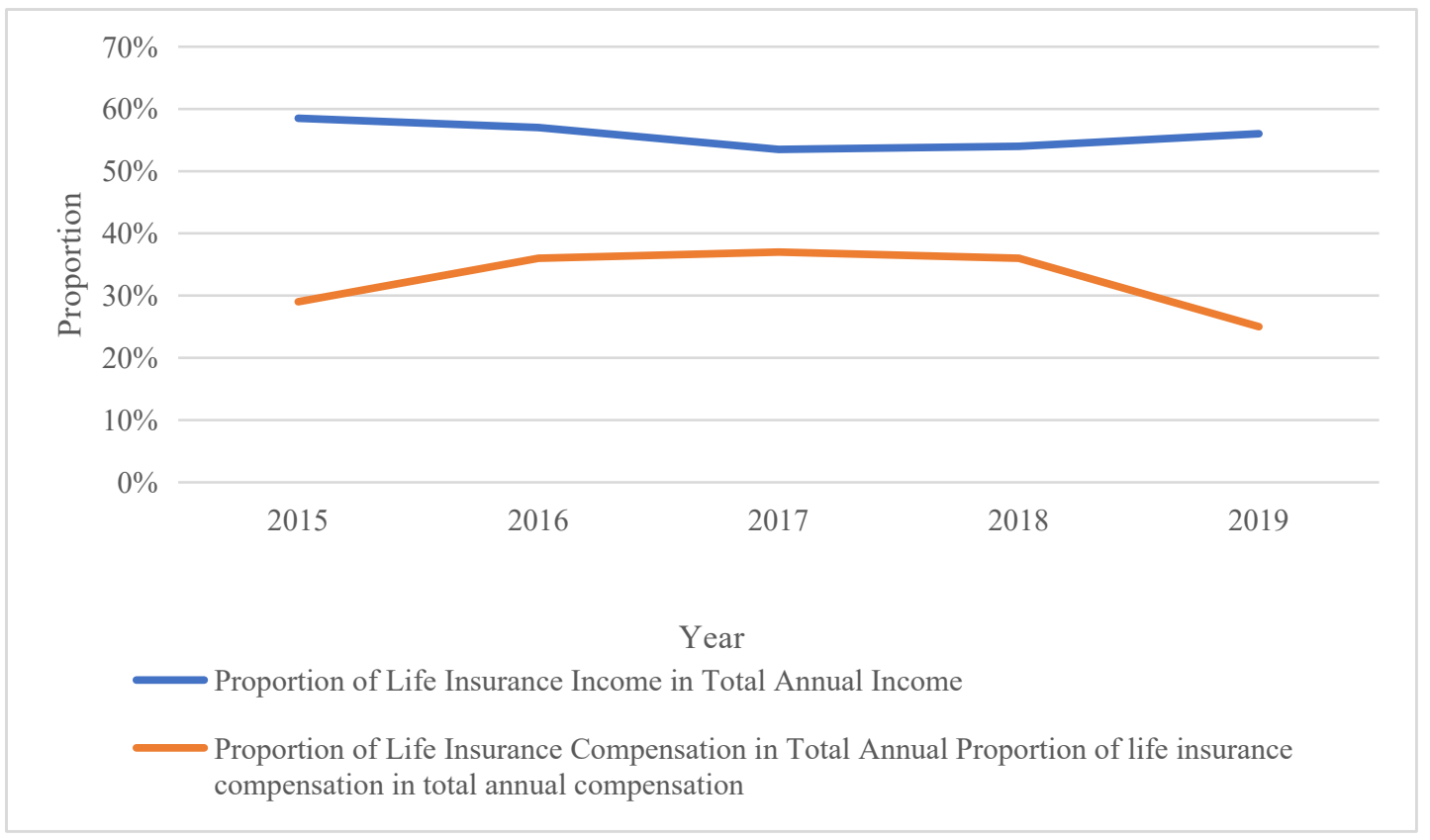

Figure 2. The Proportion of China's Life Insurance Business in the Total Scale

Shown as Figure 2, life insurance accounts for more than half of the total annual income in China's insurance industry, but the proportion of compensation has always been below $41 \%$, and there has been a trend of decrease in the past two years. This shows the seriousness of China's aging population. However, it also shows that commercial endowment insurance, as the third pillar and important supplementary force to fill the gap of pension replacement rate, still has great development space and unlimited development potential.

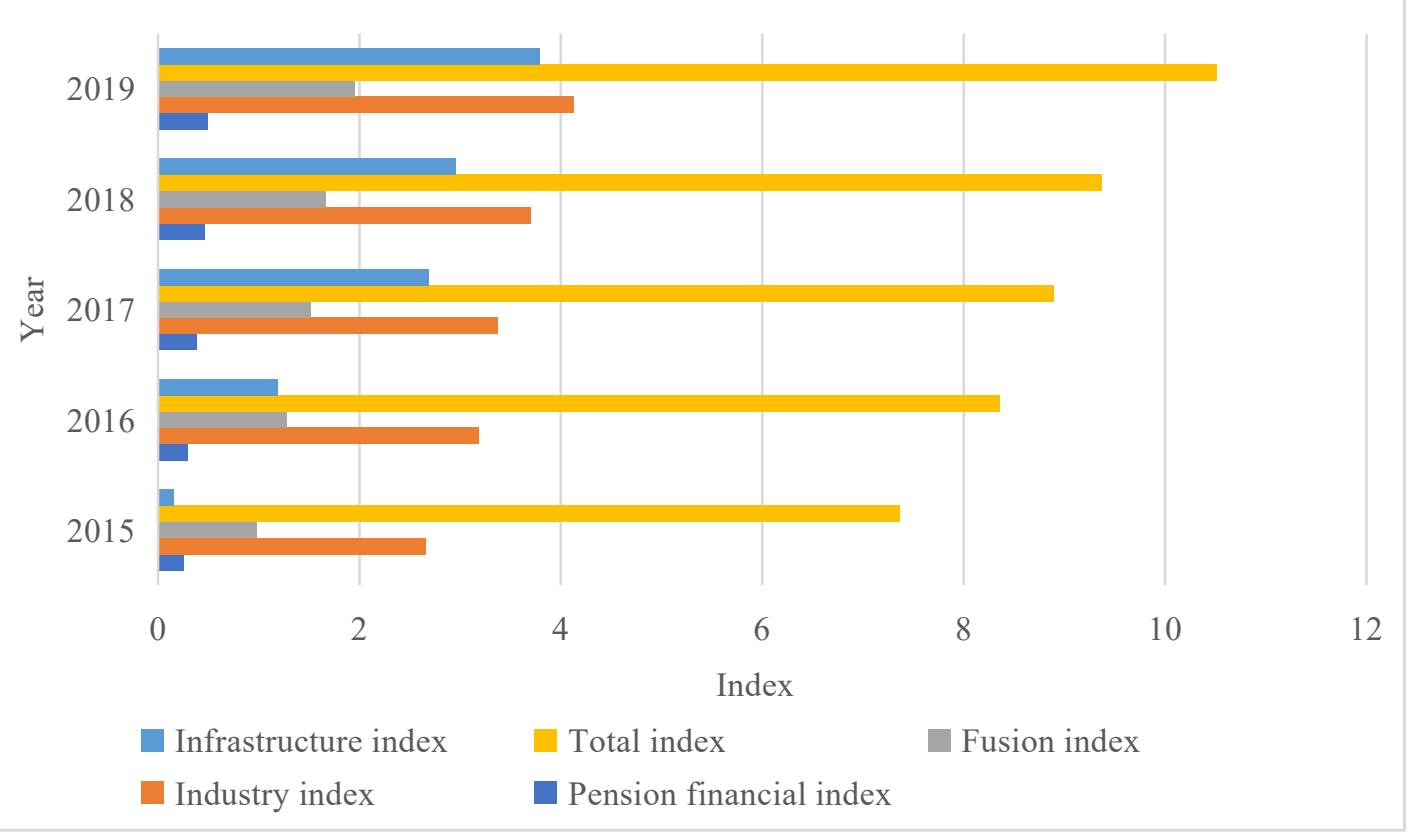

Figure 3. China's Total Index and Classification Index of Digital Economic Development in 2015-2019

Shown as in Figure 3, in the five years from 2015 to 2019, the total development level index of China's digital economy in 2019 is 10.5132 , of which the infrastructure index is 3.7854 , the industry index is 4.1299 , and the integrated application index is 1.9533. From the index values, the values are generally increasing year by year, which directly shows that all aspects of the development of digital economy in China are in a good development trend, and indirectly reflects that pension finance makes the development level of digital economy to a higher level.

\subsection{Suggestions on the Practice of Pension Economy under the Background of Digital Economy}

\subsubsection{Improve and improve the pension structure system, improve the efficiency of asset management}

In practice, it is necessary to optimize the top level of individual endowment insurance and improve the third 
pillar structure system of endowment insurance. From the international level, the optimization design of the third pillar of pension industry has three core elements, namely, account system, tax preference and diversification of investment tools. Generally speaking, the pilot projects of individual pension in the third pillar area of China are mainly product system, which is inconvenient to implement the preferential tax system. In order to effectively promote the coordinated development of various industries in China, we should actively participate in the construction of the third pillar mechanism for the elderly. Based on the current situation of China, under the condition of clear account system, all funds entering the third pillar system can enjoy certain preferential tax policies. At the same time, we should not distinguish working capital, in order to promote the coordinated development of various industries in China, Actively participate in the construction of the third pillar pension mechanism, greatly improving the convenience of operation and supervision, but also plays a very important role in the standard participation in other industries. In this process, we should constantly improve and improve the tax preferential mechanism, constantly increase the preferential intensity, and introduce investment products and tools into the personal pension insurance system. By optimizing the top-level design, we can comprehensively promote the improvement of the individual pension mechanism within the scope of the third pillar.

\subsubsection{Innovating financial products and models for the aged and expanding the scope of investment}

In recent years, with the rapid development of domestic pension financial industry, the pension financial system has been constantly improved, and the accumulation scale of pension finance has been constantly expanded. At this time, the pressure of maintaining and increasing the value of pension financial industry is increasing. In this case, we should constantly innovate and improve the form of financial products for the elderly to make them more flexible. On the basis of ensuring the security of pension assets, we should improve the income of pension investment. First, give full play to the advantages of pension funds. The concept and evaluation of domestic pension financial investment are short-term, which will have a negative impact on the maintenance and appreciation of pension insurance. Therefore, we can learn from the advanced experience of foreign countries, innovate and improve pension financial products, make pension investment long-term, so as to overcome the problems of frequent price fluctuations and poor liquidity of traditional short-term assets. Secondly, the investment scope of occupational pension and enterprise annuity should be appropriately expanded. In practice, except for non-universal insurance and related insurance, there is no difference in investment policy between enterprise annuity and occupational annuity. The trust, bank financing, infrastructure construction creditor's rights and specific asset management schemes required by the Ministry of human resources and social security into the annuity investment system can effectively broaden the investment varieties and reduce the Income Fluctuation in the annuity market.

\subsubsection{Establishing a prudent management and supervision system from the perspective of laws and regulations}

First of all, we should implement the principle of prudent supervision in the top-level design of foreign exchange management regulations. Especially in the revision of foreign exchange regulations, it is necessary to add relevant contents of prudential supervision and the three principles of industry development. For those who violate the requirements of prudential supervision and business development principles, we should formulate clear punishment measures and improve the regulatory basis of prudential supervision. Second, continue to implement the negative list management system. Through clarifying the prohibitive and restrictive provisions in the field of foreign exchange business, clarifying the market boundary of foreign exchange business, cultivating the bottom line consciousness of banks, strengthening external supervision and promoting the implementation of prudential supervision requirements in internal control link. Third, continue to simplify the foreign exchange laws and regulations management system. We should integrate and simplify the foreign exchange management laws and regulations, establish the foreign exchange supervision system, clarify the level, complete the content and make it easy to learn and master the foreign exchange management regulations, methods, rules and operating procedures, so as to promote the market entities to master and implement, promote the banks to incorporate into their own internal control, and effectively perform the business audit responsibilities designated by the foreign exchange management department.

\section{ConClusions}

At present, the development of pension finance needs policy support, market investment and operation and industrial cultivation. It is necessary to eliminate the obstacles that hinder the development of pension finance and make it develop better. In the study of the practice of pension finance in China, this paper introduces the concept of digital economy and investigates the practical problems of pension finance in the context of digital economy. There are still problems and deficiencies in the development of pension finance industry. This paper puts forward some suggestions on the development of pension finance in China, so as to comprehensively improve the quality of the development of pension finance, and provide certain reference for the design and formulation of policies.

\section{REFERENCES}

1. Boldrini M, Fulmore C A, Tartt A N, et al. Human Hippocampal Neurogenesis Persists throughout Aging[J]. Cell Stem Cell, 2018, 22(4):589-599. 
2. Maetz J Y, Cazottes S, Verdu C, et al. Precipitation and Phase Transformations in 2101 Lean Duplex Stainless Steel During Isothermal Aging[J]. Metallurgical \& Materials Transactions A, 2018, 47(1):1-15.

3. Ou H L, Björn Schumacher. DNA damage responses and p53 in the aging process[J]. Blood, 2018, 131(5): blood-2017-07-746396.

4. Yamamoto R, Wilkinson A C, Ooehara J, et al. LargeScale Clonal Analysis Resolves Aging of the Mouse Hematopoietic Stem Cell Compartment[J]. Cell Stem Cell, 2018, 22(4):600-607.

5. Boldrini M, Fulmore C A, Tartt A N, et al. Human Hippocampal Neurogenesis Persists throughout Aging[J]. Cell Stem Cell, 2018, 22(4):589-599.

6. Nikolich-ugich, Janko. The twilight of immunity: emerging concepts in aging of the immune system[J]. Nature Immunology, 2018, 19(1):10-19.

7. Willis R J. Theory confronts data: how the HRS is shaped by the economics of aging and how the economics of aging will be shaped by the HRS[J]. Labour Economics, 2018, 6(2):119-145.

8. Voosen, Paul. Saildrone fleet could help replace aging buoys[J]. ence, 2018, 359(6380):1082-1083.

9. Levine M E, Lu A T, Quach A, et al. An epigenetic biomarker of aging for lifespan and healthspan[J]. Aging, 2018, 10(4):573-591.

10. Novoselov V M. Is Aging a Disease?[J]. Advances in Gerontology, 2018, 8(2):119-122. 